\title{
ETHANOL EXTRACT OF MARIGOLD FLOWER (Tagetes Erecta L.) DECREASES THE TOTAL CHOLESTEROL, LOW DENSITY LYPOPROTEIN (LDL), MALONDIALDEHYDE (MDA), AND APOLIPROTEIN B (APOB) ON HYPERLIPIDEMIA RAT MODELS
}

\author{
I Nyoman Bagus Aji Kresnapati ${ }^{1}$, Siti Khaerunnisa ${ }^{2}$, Indri Safitri ${ }^{3}$ \\ ${ }^{1}$ Postgraduate of Basic Medical Science, Faculty of Medicine, Universitas Airlangga, Surabaya, Indonesia \\ ${ }^{2}$ Department of Biochemistry, Faculty of Medicine, Universitas Airlangga, Surabaya, Indonesia \\ ${ }^{3}$ Department of Physiology and Medical Biochemistry, Faculty of Medicine, Universitas Airlangga, Surabaya, \\ Indonesia
}

\section{ABSTRACT}

This study aimed to determine the effect of ethanol extract of gemitir flower (Tagetes erecta L.) on total cholesterol levels, LowDensity Lipoprotein C (LDL), Malondialdehyde (MDA), Apolipoprotein B (ApoB). Forty-eight Rattus norvegicus were randomly divided into 6 groups, groups were given standard feed $(K-)$ and 5 groups of hyperlipidemia models $(K+, P 1, P 2$, P3, P4) were given High Fat Diet (HFD) for 35 days. On the 36th day, the total cholesterol levels were checked through the tail of Rattus norvegicus, and from day 37 to day 50 were given a normal diet $(K-), H F D(K+)$, simvastatin $10 \mathrm{mg} / \mathrm{kgBW}(P 1)$, ethanol extract of gemitir flowers (Tagetes erecta L.) 200 (P2), $400 \mathrm{BW}(\mathrm{P3})$, and $800 \mathrm{mg} / \mathrm{kgBW}(P 4)$. On day 51, the total cholesterol, LDL-C, MDA, and ApoB blood serum levels were checked. The results showed total cholesterol, Low-Density Lipoprotein (LDL), Malondialdehyde (MDA), and Apolipoprotein B (ApoB) given ethanol extract of gemitir flowers 200 and $400 \mathrm{mg} / \mathrm{kgBW}(P 2)$ had a significant reduction $(P<0.05)$. Giving ethanol extract of gemitir flower (Tagetes erecta L.) could reduce levels of total cholesterol, $L D L, M D A$, and Apo $B$.

Keywords: ApoB; LDL; marigold flower (Tagetes erecta L); total cholesterol; MDA; cardiovascular disease

\begin{abstract}
ABSTRAK
Penelitian ini bertujuan untuk mengetahui efek ekstrak etanol bunga gemitir (Tagetes erecta L.) terhadap kadar kolesterol total, Low Density Lipoprotein (LDL), Malondialdehyde (MDA), Apolipoprotein B (ApoB). Empat puluh delapan ekor Rattus norvegicus secara acak dibagi menjadi 6 kelompok, kelompok diberikan pakan standar $(K-)$ dan 5 kelompok model hiperlipidemia $(K+, P 1, P 2, P 3, P 4)$ yang diberikan High Fat Diet (HFD) selama 35 hari. Hari ke-36 diperiksa kadar kolesterol total melalui ekor Rattus norvegicus dan mulai hari ke-37 hingga hari ke-50 diberikan diet normal $(K-), H F D(K+)$, simvastatin $10 \mathrm{mg} / \mathrm{kgBB}(P 1)$, ekstrak etanol bunga gemitir (Tagetes erecta L.) 200 (P2), 400 BB (P3), dan $800 \mathrm{mg} / \mathrm{kgBB}(P 4)$. Pada hari ke-51 di periksa kadar kolesterol total, LDL, MDA dan ApoB darah serum. Hasil menunjukkan kolesterol total, Low Density Lipoprotein (LDL), Malondialdehyde (MDA), dan Apolipoprotein B (ApoB) yang diberikan ekstrak etanol bunga gemitir 200 dan $400 \mathrm{mg} / \mathrm{kgBB}(P 2)$ memiliki penurunan secara bermakna $(P<0.05)$. Pemberian ekstrak etanol bunga gemitir (Tagetes erecta L.) dapat menurunkan kadar kolesterol total, $L D L C, M D A$, dan Apo B.
\end{abstract}

Kata kunci: ApoB; LDL; bunga gemitir (Tagetes erecta L.); kolesterol total; MDA; cardiovascular disease

Correspondence: Indri Safitri, Department of Physiology and Medical Biochemistry, Faculty of Medicine, Universitas Airlangga, Surabaya, East Java 60286. Email: indrisafitri@yahoo.com

pISSN:2355-8393 • eISSN: 2599-056x • doi: 10.20473/fmi.v57i3.23838

- Fol Med Indones. 2021;57:245-249 • Submitted 14 Dec $2020 \bullet$ Received 31 Mar $2021 \bullet$ Accepted 12 Apr 2021

- Open access under CC-BY-NC-SA license • Available at https://e-journal.unair.ac.id/FMI/ 


\section{INTRODUCTION}

Cardiovascular disease is one of the leading causes of death in the worldwide. Deaths due to this disease were around 17.5 million of deaths in worldwide in 2012, and are expected to continue to increase (World Health Organization 2010). One of the factors causing cardiovascular disease is hyperlipidemia. Hyperlipidemia is a condition characterized by an increase in plasma cholesterol levels (hypercholesterolemia), Triacylglycerols, Low-Density Lipoprotein (LDL) (Singh et al 2017), and Apolipoprotein B (ApoB) in the blood (Itabe 2009, Shattat 2014).

The increased cholesterol levels can change membrane lipids to form Reactive Oxygen Species (ROS) that causes damage to DNA, membrane lipids, and proteins (Li et al 2014). Under normal conditions, there is a balance of Reactive Oxygen Species (ROS) and antioxidant defense systems. An imbalance between Reactive Oxygen Species and antioxidants causes stress oxidative (Carlos 2019). Malondialdehyde (MDA) is a biomarker of oxidative stress due to the occurrence of lipid peroxidation of Polyunsaturated Fatty Acids (PUFA) (Yang et al 2008). Reactive Oxygen Species (ROS) such as Anion Superoxide (O2•-) degrade polyunsaturated lipids to form MDA. Malondialdehyde (MDA) is a biomarker in measuring the level of oxidative stress in living organisms (Singh et al 2017).

Reactive Oxygen Spesies (ROS) reduces one electron oxygen molecule to Anion Superoxide (O2•-) radical. Cells actually have defense enzymes to reduce Anion Superoxide $(\mathrm{O} 2 \bullet-)$ formation. Superoxide Dismutase (SOD) is an endogenous antioxidant enzyme to protect cells from the harmful effects of Anion Superoxide (O2•-). Superoxide Dismutase (SOD) converts O2• into $\mathrm{H} 2 \mathrm{O} 2$ which is not radical. The enzyme 3Hydroxy-3-Methylglutaril-Coenzyme A (HMG-CoA) reductase is a rate limiting enzyme that catalyzes the conversion of HMG-CoA to mevalonate in the cholesterol biosynthesis pathway. The reaction catalyzed by HMG-CoA reductase is the target of antihypercholesterolemic drugs which reduce serum cholesterol levels (Friesen and Rodwell, 2004). Statins inhibit HMG-CoA reductase and reduce serum cholesterol levels efficiently from Low-Density Lipoprotein C (LDL). However, long-term consumption of statins causes serious consequences such as liver and muscle disorders (Baskaran et al 2015).

Marigold flowers (Tagetes erecta L.) are ornamental plants commonly used for worship in Bali (Pramitha et al 2012). This flower has antioxidant, anti-bacterial, and hepatoprotective activity (Gopi et al 2012). The content of marigold flower (Tagetes erecta L.) that have antioxidant activity includes flavonoids, carotenoids ( $\beta$ carotene, lutein, lycopene), tannins, saponins, xanthophylls and zeaxanthin (Siriamornpun et al 2012). Marigold flower (Tagetes erecta L.) contains flavonoids (Pramitha et al 2018) which function to reduce Anion Superoxide $(\mathrm{O} 2 \bullet-)$ to prevent a decrease in the activity of the Superoxide Dismutase (SOD) enzyme.

Flavonoids suppress lipid biosynthetic pathways such as oxLDL oxidation and inflammation of the artery walls (Manzoni et al 2019). Carotenoids (lycopene, $\beta$ carotene, and lutein) in marigold flower (Friesen \& Rodwell 2004) reduce cholesterol levels by inhibiting HMG-CoA reductase activity (Kulczyński et al 2017). Lutein extract from marigold flowers which has the potential as an antioxidant is characterized by a decrease in levels of MDA in experimental animals. Therefore, it was necessary to conduct a study on the antihyperlipidemic potential of marigold flower (Tagetes erecta L.) extract in experimental animals with hyperlipidemia models (Kusmiati et al 2019).

\section{MATERIALS AND METHODS}

\section{Extraction of marigold flower (Tagetes erecta L.)}

Marigold flower (Tagetes erecta L.) fresh in weight of $10 \mathrm{~kg}$ were taken from Karangasem Bali, cleaned, airdried and macerated in ethanol $96 \%$ until all were completely immersed, in about 3x24 hours. The extract filtered and concentrated using a rotary vacuum evaporator to obtain a thick extract. The flavonoid content of the extract was measured using Willstatter test (phytochemical test).

\section{Making hyperlipidemia rat model}

Forty-eight male rats (strain Wistar novergicus), aged 3 to 4 months and weighing 180-200 grams were adapted for 7 days, after which they were divided into 2 groups, eight samples in $\mathrm{K}$ - were given standard feed and fourty Rattus norvegicus hyperlipidemic models ( $\mathrm{K}+, \mathrm{P} 1, \mathrm{P} 2$, P3 and P4) were given HFD for 35 days. On the 36th day, blood was drawn through the tail to check total cholesterol levels using the Autocheck Analyzer@ (Raghuver et al 2011).

\section{Treatment}

Six groups with eight rats for each group were divided into; given standard feed (K-), High Fat Diet (HFD) (K + ), simvastatin $10 \mathrm{mg} / \mathrm{kgBW}$ (P1), marigold flower ethanol extract (Tagetes erecta L.) 200 (P2), 400 (P3), and $800 \mathrm{mg} / \mathrm{kgBW}(\mathrm{P} 4)$ for 14 days. On the day 51, all 
mice were sacrificed to check for total cholesterol, LDL, MDA, and ApoB levels.

Profile Lipids examinations were measured using Cholesterol Oxidase Method (CHOD-PAP). in Surabaya Laboratory Health (BBLK) and ApoB and MDA were measured using Bioassay Technology Laboratory reagent kit ELISA in Institute Tropical Disease Center, Universitas Airlangga.

\section{Statistical analysis}

Statistical tests used SPSS version 25. Data were presented as mean \pm SEM and for 'One-Way Analysis of Variance' (ANOVA), and 'T Test' to compare the Kwith Rattus norvegicus hyperlipidemic models $(\mathrm{K}+, \mathrm{P} 1$,
P2, P3 and P4). $\mathrm{p}$ value $<0.05$ was considered significant.

\section{RESULTS}

The results of cholesterol, HDL and LDL Rattus norvegicus in the negative control group that was not treated with the High Fat Diet (HFD) with the positive control group, treatment 1, treatment 2, treatment 3 and treatment 4 with the High Fat Diet (HFD) treatment, and continued simvastatin and gemitir flower extract (Tagetes erecta L) as follows:

Table 1. The characteristics of subjects

\begin{tabular}{|c|c|c|c|c|c|}
\hline \multirow[t]{3}{*}{ Groups } & Pre-Total Cholesterol & Total Cholesterol & LDL & MDA & APOB \\
\hline & Mean \pm SD & Mean \pm SD & Mean \pm SD & Mean \pm SD & Mean \pm SD \\
\hline & $\mathrm{mg} / \mathrm{dL}$ & $\mathrm{mg} / \mathrm{dL}$ & $\mathrm{u} / \mathrm{L}$ & $\mathrm{nmol} / \mathrm{ML}$ & ng/ML \\
\hline $\mathrm{K}-$ & $118.57 \pm 5.65$ & $47,00 \pm 4,79$ & $7,86 \pm 1,57$ & $0,92 \pm 0,23$ & $0,83 \pm 0,068$ \\
\hline $\mathrm{K}+$ & $142.86 \pm 8.21$ & $59,14 \pm 6,72$ & $11,86 \pm 3,80$ & $1,197 \pm 0,125$ & $0,92 \pm 0,07$ \\
\hline $\mathrm{P} 1$ & $137.14 \pm 9.29$ & $53,14 \pm 7,47$ & $8,57 \pm 1,39$ & $1,00 \pm 0,116$ & $0,85 \pm 0,06$ \\
\hline $\mathrm{P} 2$ & $139.57 \pm 10.73$ & $49,43 \pm 4,03$ & $8,71 \pm 2,0$ & $0,95 \pm 0,14$ & $0,81 \pm 0,05$ \\
\hline P3 & $144.57 \pm 10.34$ & $48,14 \pm 3,43$ & $8,29 \pm 2,0$ & $0,807 \pm 0,20$ & $0,71 \pm 0,12$ \\
\hline $\mathrm{P} 4$ & $140.86 \pm 9.335$ & $52,57 \pm 7,02$ & $7,86 \pm 2,11$ & $1,10 \pm 0,14$ & $0,95 \pm 0,9$ \\
\hline
\end{tabular}

Note: In the Pre-Total Cholesterol, there was an increase in total cholesterol levels in the HFD group for 35 days $(\mathrm{K}+$, P1, P2, P3, and P4). Total cholesterol, LDL, MDA and ApoB were checked on the 51th day after given HFD (K +), simvastatin $10 \mathrm{mg} / \mathrm{kg} / \mathrm{BW}(\mathrm{P} 1)$, ethanol extract of marigold flower 200 (P2), 400 (P3) and $800 \mathrm{mg} / \mathrm{kgBW}$ (P4)

The previous table indicated that Rattus norvegicus given ethanol extract of gemitir flowers had an average pre-total cholesterol, total cholesterol, LDL, MDA and Apo-B levels lower than those given the High Fat Diet (HFD). These differences could be observed in the following graph.

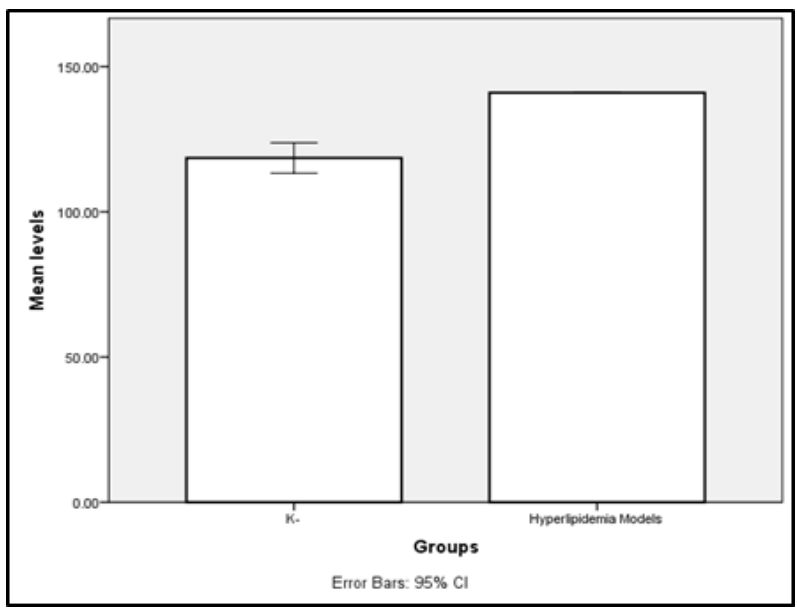

Figure 1. Rattus norvegicus hyperlipidemic model ( $\mathrm{K}+$, P1, P2, P3, and P4) were given HFD for 35 days. On day 36 , total cholesterol levels were measured by taking blood in the tail of Rattus norvegicus and the mean total cholesterol level was $141.02 \mathrm{mg} / \mathrm{dL}$ increased significantly $(\mathrm{P}=0.000)$ compared to the average group $\mathrm{K}$ - which was $118.57 \mathrm{mg} / \mathrm{dL}$.

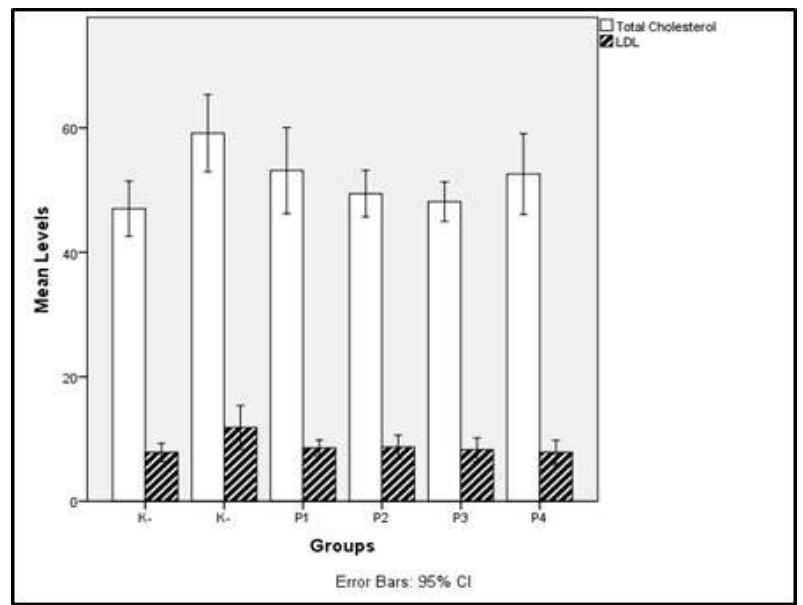

Figure 2. Total cholesterol (white) and LDL (striped) levels after being given HFD, simvastatin $10 \mathrm{mg} / \mathrm{kgBW}$, ethanol extract of gemitir flowers 200, 400 and 800 $\mathrm{mg} / \mathrm{kgBW}$, respectively for 14 days after hyperlipidemia models were made for 35 day. The results showed a 
significant decrease $(\mathrm{p}<0.05)$ after being given simvastatin and marigold flower extract 200 and 400 $\mathrm{mg} / \mathrm{kgBW}$ (except $\mathrm{P} 4=800 \mathrm{mg} / \mathrm{kgBW}$ ) compared to $\mathrm{K}$ + .

Figure 1 showed that there was a significant increase in total cholesterol levels between the K-group and the hyperlipidemia group after examining the tail of Rattus norvegicus on day 36 . Then, on the 51st day the cholesterol, LDL, MDA, and Apo-B levels were checked.

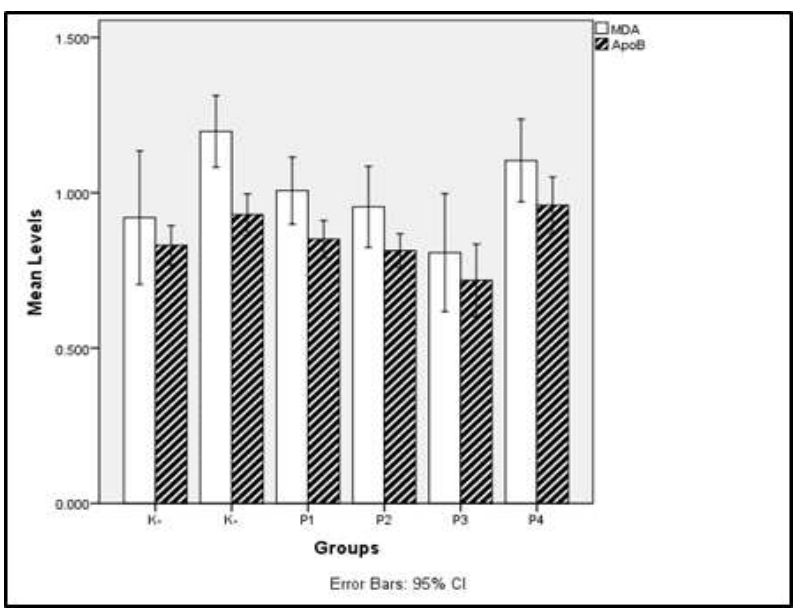

Figure 3. Malondialdehyde (MDA) (white) and ApoB (striped) after being given the standard drug simvastatin $10 \mathrm{mg} / \mathrm{kgBW}$ (P1) and ethanol extract of marigold flowers at a dose of 200 (P2); 400 (P3) and 800 $\mathrm{mg} / \mathrm{kgBW}$ (P4) for 14 days in the Rattus norvegicus hyperlipidemia model, had shown a significant decrease in MDA levels at $200 \mathrm{mg} / \mathrm{kgBW}$ (P2) (0.006) and apoB at $400 \mathrm{mg} / \mathrm{kgBW}(\mathrm{P} 3)(\mathrm{P}=0.000)$

\section{DISCUSSION}

Cholesterol levels in experimental hyperlipidemia models can be seen in Figure 1. After 35 days of HFD administration, there was an increase in total cholesterol levels. This was in accordance with a study of Raghuver et al (2011) that giving HFD for 30 days could increase total cholesterol levels in Rattus Norvegicus.

Pulungan and Pane (2020) also reported that giving HFD to Rattus Novergicus for 28 days also increased cholesterol levels. The increase in total cholesterol levels was caused by the induction of a high cholesterol diet in a mixture of lard and duck egg yolk. Pork fat contained saturated fatty acid levels. and higher cholesterol than other animal oils. The saturated fatty acid (SFA) content of lard (lard) was $43.95 \%$ (Lingzhi et al 2016), and duck egg yolk was $31.85 \%$ (Polat et al 2013). Saturated Fatty Acids (SFA) increased total cholesterol and Low-Density Lipoprotein (LDL-C) which was at risk for Coronary Heart Disease (CHD). High levels of fatty acids stimulated the synthesis of Triacylglycerides (TG) in the liver and excrete them in the form of Very Low Density Lipoprotein (VLDL). High VLDL could increase levels of Low Density Lipoprotein (LDL-C) cholesterol. The liver synthesized cholesterol to be secreted in the form of lipoproteins (VLDL, IDL, LDL) and eliminated excess cholesterol by converting cholesterol into bile acids to be secreted into the intestinal lumen (Chan et al 2015).

Giving Marigold flower (Tagetes erecta L.) extract could reduce cholesterol and LDL levels (Figure 2), because the lycopene in marigold flowers (Tagetes erecta L.) could inhibit HMG CoA Reductase (Gopi et al 2012), thereby reducing synthesis of cholesterol and indirectly also reduced LDL and Apolipoprotein B (ApoB), because LDL was the main lipoprotein that transports cholesterol (Jiang et al 2016).

Figure 3 showed the increase of total cholesterol in HFD groups $(\mathrm{K}+)$ compared to other group. Hypercholesterolemia increased Low Density Lipoprotein (LDL) and oxLDL, and increased the migration of macrophages in digesting oxLDL into foam cells. Besides, hypercholesterolemia increased the activation of the mitochondrial electron system or the activation of NADPH oxidase macrophages in producing Reactive Oxygen Species (ROS) (Xu et al 2016), such as Anion Superoxide (O2•-). Nitric oxide (NO) was an endogenous antioxidant produced by endothelial cells and when it binds to Anion Superoxide (O2•-) that created Peroxynitrite $\left(\mathrm{NO}^{-}-\right.$), and with $\mathrm{H}+$ to form peroxynitric acid as well as broken down into Hydroxyl Radicals (OH•) (Yoshida \& Kisugi 2010). Hydroxyl Radicals $(\mathrm{OH} \bullet)$ could initiate lipid peroxidation by binding to Polyunsaturated Fatty Acids (PUFA), such as LDL. The result of lipid peroxidation formed toxic compounds including Malondialdehyde (MDA) (Treml \& Smejkal 2016).

Malondialdehyde (MDA) and ApoB decreased after giving marigold ethanol extract (Figure 3). Nitrite Oxide (NO) was anti-inflammatory, anticoagulant and vasodilator on endothelial cells (Fukai \& Ushio 2011). The normal function of endothelial cells was characterized by a balance of Nitrite Oxide (NO) and ROS. Lycopene in Marigold flower (Tagetes erecta L.) could increase the bioavailability of NO by directly reducing Anion Superoxide (O2•-) (Siriamornpun et al 2012, Rane et al 2019), thereby minimizing the formation of Hydroxyl Radicals $(\mathrm{OH} \bullet)$ and Malondialdehyde (MDA) (Kusmiati et al 2019). 


\section{CONCLUSION}

Ethanol extract Marigold flowers (Tagetes erecta L.) significantly reduced total cholesterol, LDL, MDA, and ApoB levels, at doses of 200 and $400 \mathrm{mg} / \mathrm{kgBW}$. However, further research was necessary to explore the effect of ethanol extract of Marigold flowers on other hyperlipidemic variables, such as TG, Apo A, and HDL.

\section{REFERENCES}

Baskaran G, Salvamani S, Azlan A, et al (2015). Hypocholesterolemic and antiatherosclerotic potential of Basella alba leaf extract in hypercholesterolemiainduced rabbits. Evidence-Based Complementary and Alternative Medicine 2015, 1-8.

Carlos CC (2019). Reactive oxygen species: training, function and oxidative stress. Medicina Legal de Costa Rica 36, 91-100.

Chan J, Karere GM, Cox LA, et al (2015). Animal models of diet-induced Hypercholesterolemia. IntechOpen, Rijeka.

Friesen JA, Rodwell VM (2004). The 3-hydroxy-3methylglutaryl coenzyme-A (HMG-CoA) reductases. Genome Biology 5, 1-7.

Fukai T, Ushio-Fukai M (2011). Superoxide dismutases: role in redox signaling, vascular function, and diseases. Antioxidants \& Redox Signaling 15, 15831606.

Gopi G, Elumalai A, Jayasri P (2012). A concise review on Tagetes erecta. International Journal of Phytopharmacy Research 3, 16-19.

Itabe H (2009). Oxidative modification of LDL: Its pathological role in atherosclerosis. Clinical Reviews in Allergy \& Immunology 37, 4-11.

Jiang W, Guo MH, Hai X (2016). Hepatoprotective and antioxidant effects of lycopene on non-alcoholic fatty liver disease in rat. World Journal of Gastroenterology 22, 10180-10188.

Kulczyński B, Gramza-Michałowska A, KobusCisowska J, et al (2017). The role of carotenoids in the prevention and treatment of cardiovascular disease: Current state of knowledge. Journal of Functional Foods 38, 45-65.

Kusmiati K, Caesarianto W, Afiati F, et al (2019). Effect lutein of marigold flower (Tagetes erecta L.) on decreasing glucose and malondialdehyde levels in Alloxan-induced blood mice. AIP Conference Proceedings 2120, 1-7.

Li P, Jia J, Zhang D, et al (2014). In vitro and in vivo antioxidant activities of a flavonoid isolated from celery (Apium graveolens L. var. dulce). Food \& Function 5, 50-56.
Lingzhi X, Fei G, Zengling Y, et al (2016). Discriminant analysis of terrestrial animal fat and oil adulteration in fish oil by infrared spectroscopy. International Journal of Agricultural and Biological Engineering 9, 179-185.

Manzoni AG, Passos DF, da Silva JL, et al (2019). Rutin and curcumin reduce inflammation, triglyceride levels and ADA activity in serum and immune cells in a model of hyperlipidemia. Blood Cells, Molecules, and Diseases 76, 13-21.

Pramitha DAI, Suaniti NM, Sibarani J (2018). Aktivitas antioksidan bunga pacar air merah (Impatiens balsamina L.) dan bunga gemitir (tagates erecta L.) dari limbah canang. Chimica et Natura Acta 6, 8-11.

Pulungan A, Pane YS (2020). The benefit of cinnamon (Cinnamomum burmannii) in lowering total cholesterol levels after consumption of high-fat containing foods in white mice (Mus musculus) models. F1000Research 9, 1-15.

Raghuveer R, Sreeja K, Sindhuri T, et al (2011). Antihyperlipidemic effect of Tagetes erecta in cholesterol fed hyperlipidemic rats. Der Pharmacia Lettre 3, 266-270.

Rane BT, Worlikar PS, Mulkalwar SA, et al (2019). Evaluation of the effect of lycopene on lipid profile, serum antioxidant enzymes and blood sugar level in New Zealand white (NZW) rabbits. International Journal of Basic \& Clinical Pharmacology 7, 1-8.

Shattat GF (2014). A review article on hyperlipidemia: Types, treatments and new drug targets. Biomedical \& Pharmacology Jurnal 7, 399-409.

Singh UN, Kumar S, Dhakal S (2017). Study of oxidative stress in hypercholesterolemia. Int J Contemp Med Res 4, 1204-1207.

Siriamornpun S, Kaisoon O, Meeso N (2012). Changes in colour, antioxidant activities and carotenoids (lycopene, $\beta$-carotene, lutein) of marigold flower (tagetes erecta L.) resulting from different drying processes. Journal of Functional Foods 4, 757-766.

Treml J, Šmejkal K (2016). Flavonoids as potent scavengers of hydroxyl radicals. Comprehensive Reviews in Food Science and Food Safety 15, 720738.

World Health Organization (2019). Cardiovascular disease (CVDs). Available from https://www.who.int/. Accessed November 17, 2020.

Yang RL, Shi YH, Hao G, et al (2008). Increasing oxidative stress with progressive hyperlipidemia in human: Relation between malondialdehyde and atherogenic index. Journal of Clinical Biochemistry and Nutrition 43, 154-158.

Yoshida H, Kisugi R (2010). Mechanisms of LDL oxidation. Clinica Chimica Acta 411, 1875-1882. 